\title{
PENGARUH MOTIVASI DAN KOMPETENSI TERHADAP KINERJA DOSEN TETAP DI SEKOLAH TINGGI PARIWISATA BALI INTERNASIONAL DENPASAR
}

\author{
Ni Made Christina Gariyasa ${ }^{1}$ \\ Universitas Triatma Mulya \\ Email: christinagariyasa10@gmail.com
}

\begin{abstract}
ABSTRAK
Kualitas akademik sebuah perguruan tinggi tidak lepas dari keberhasilannya menyelenggarakan Tri Dharma Perguruan Tinggi, yaitu Pendidikan, Penelitian dan Pengabdian Kepada Masyarakat. Perguruan Tinggi dituntut untuk terus mengembangkan tiga keunggulan, yaitu keunggulan dalam pendidikan, penelitian dan pengabdian kepada masyarakat terkait pemanfaatan dan penerapan ilmu pengetahuan, teknologi, dan seni (IPTEKS). Penelitian ini bertujuan untuk menganalisis efek motivasi dan kompetensi terhadap kinerja dosen tetap. Jumlah sampel dalam penelitian ini adalah 63 responden. Teknik pengumpulan data dalam penelitian ini adalah kuesioner dan dokumentasi. Pengambilan sampel menggunakan teknik sensus, yaitu teknik pengambilan sampel yang dilakukan pada tujuan dan pertimbangan tertentu. Metode penelitian yang digunakan dalam penelitian ini adalah metode kuantitatif. Dalam analisis beberapa regresi linear yang diperoleh persamaan adalah $\mathrm{Y}=4.048+0.204 \mathrm{X} 1+0.238 \mathrm{X} 2$. Selain itu juga terbukti bahwa pengaruh motivasi terhadap kinerja Dosen Tetap di Sekolah Tinggi Pariwisata Bali Internasional merupakan efek positif dan signifikan, yang dibuktikan dengan adanya nilai probabilitas kurang dari 0,05 yaitu 0,04 . Sedangkan pengaruh kompetensi terhadap kinerja Dosen Tetap di Sekolah Tinggi Pariwisata Bali Internasional menunjukkan efek positif dan signifikan, yang dibuktikan dengan adanya nilai probabilitas yang lebih kecil dari 0,05 yaitu 0,008. Untuk pengaruh motivasi dan kompetensi terhadap kinerja dosen tetap di Sekolah Tinggi Pariwisata Bali Internasional sebesar 39,9\%.
\end{abstract}

Kata Kunci: Motivasi, kompetensi dan kinerja Dosen

\section{ABSTRACT}

The academic quality of a tertiary institution cannot be separated from its success in organizing the Tri Dharma of Higher Education, namely Education, Research and Community Service. Higher Education is required to continuously develop three advantages, namely excellence in education, research and community service related to the utilization and application of science, technology, and art (IPTEKS). This study aims to analyze the effect of motivation and competence on the 
performance of permanent lecturers. The number of samples in this study were 63 respondents. Data collection techniques in this study are questionnaires and documentation. Sampling uses a census technique, which is a sampling technique that is carried out on certain objectives and considerations. The research method used in this study is a quantitative method. In the analysis of multiple linear regression obtained equation is $Y=4.048+0.204 X 1+0.238 X 2$. In addition to this it is also proven that the influence of Motivation on the Performance of Permanent Lecturers at Sekolah Tinggi Pariwisata Bali Internasional is a positive and significant effect, as evidenced by the existence of a probability value of less than 0.05 which is 0.04. While the influence of Competence on the Performance of Permanent Lecturers at Sekolah Tinggi Pariwisata Bali Internasional showed a positive and significant effect, as evidenced by the existence of a probability value smaller than 0.05 which is 0.008 . For the influence of motivation and competence on the performance of permanent lecturers at Sekolah Tinggi Pariwisata Bali Internasional is $39.9 \%$.

Keywords: Motivation, competence and performance of lecturers

\section{PENDAHULUAN}

Kualitas akademik suatu perguruan tinggi tidak lepas dari keberhasilannya dalam penyelenggaraan Tri Dharma Perguruan Tinggi, yaitu Pendidikan, Penelitian dan Pengabdian kepada Masyarakat. Menurut data Simlitabmas Ristekdikti, Sekolah Tinggi Pariwisata Bali Internasional menempati peringkat 294 dari 1.977 PT (PTN dan PTS Seluruh Indonesia), masuk pada kelompok/klaster Madya. Selain itu juga menurut simlitabmas kinerja pengabdian kepada masyarakat Sekolah Tinggi Pariwisata Bali Internasional pada tahun 2019 sudah masuk klaster memuaskan yang pada tahun sebelumnya masih pada klaster kurang memuaskan.

Akan tetapi kompetensi para dosen Sekolah Tinggi Pariwisata Bali Internasional masih belum baik. Berdasarkan pangkalan data pendidikan tinggi (PDDIKTI), tingkat pendidikan dosen tetap STPBI hampir 80\% masih S2 dan hanya memiliki 13 dosen yang sudah bergelar doktor. Berdasarkan laporan kinerja tahunan PPPM STPBI, menyatakan bahwa motivasi dosen untuk pelaksanakan penelitian dan pengabdian kepada masyarakat sangat rendah. Hampir $70 \%$ dosen terlalu berfokus dalam pengajaran. Hal ini dibuktikan dari beban kerja dosen yang memperlihatkan jumlah sks pengajaran lebih besar dari pada penelitian dan pengabdian kepada masyarakat. Bahkan kebijakan STPBI tidak mencantumkan adanya punishment dan reward dari perguruan tinggi terhadap pelaksanaan penelitian dan pengabdian kepada masyarakat. Menurut Ketua PPPM Sekolah Tinggi Pariwisata Bali Internasional menyatakan bahwa masih lemah budaya meneliti dan pengabdian di kampus.

Jika mengacu pada teori seharusnya kompetensi dan motivasi dapat mempengaruhi kinerja dosen. Menurut Pramudyo (2010:1) motivasi dan kompetensi yang tinggi akan dapat meningkatkan kinerja dosen. Selain itu menurut I'tidal dan Jam'an (2016:16) menyatakan kompetensi, motivasi kerja dan pendidikan berpengaruh signifikan terhadap kinerja dosen. Berdasarkan hal 
tersebut, sangat menarik untuk diteliti mengenai Pengaruh Motivasi dan Kompetensi Terhadap Kinerja Dosen Tetap di Sekolah Tinggi Pariwisata Bali Internasional.

\section{METODE PENELITIAN}

Berdasarkan permasalahan yang telah dirumuskan, penelitian ini menggunakan metode kuantitatif. Metode ini digunakan untuk meneliti pada populasi atau sampel tertentu, Teknik pengambilan sampel pada umumnya secara random, kumpulan data menggunakan instrumen penelitian, analisis data bersifat kuantitatif dengan tujuan untuk menguji hipotesis yang telah ditetapkan (Sugiyono, 2013: 39).

Penelitian ini bertempat di Sekolah Tinggi Pariwisata Bali Internasional yang lokasinya berada di Jalan Tari Kecak No.12 Gatot Subroto Timur Kota Denpasar Provinsi Bali. Teknik pengumpulan data yang digunakan adalah kuesioner. Kuesioner yang digunakan dalam penelitian menggunakan kuesioner tertutup dengan skala pengukuran untuk semua indikator pada masing-masing variabel menggunakan skala likert dimulai dari sangat tidak setuju (STS) sampai dengan sangat setuju (SS), skala pengukuran yang digunakan adalah sebagai berikut:

1. Jawaban diberi skor 5 dengan kategori sangat setuju.

2. Jawaban diberi skor 4 dengan kategori setuju.

3. Jawaban diberi skor 3 dengan kategori cukup setuju.

4. Jawaban diberi skor 2 dengan kategori tidak setuju.

5. Jawaban diberi skor 1 dengan kategori sangat tidak setuju

Teknik analisis data yang digunakan dalam penelitian ini adalah menggunakan analisis regresi linear berganda. Analisis regresi linier berganda adalah hubungan secara linear antara dua atau lebih variabel independen Motivasi (X1), Kompetensi (X2), dengan variabel dependen Kinerja Dosen Tetap (Y), analisis ini untuk mengetahui akan hubungan antara variabel independen dengan variabel dependen apakah positif atau negative dan untuk memprediksi nilai dari variabel dependen apabila nilai variabel independen mengalami kenaikan atau penurunan data yang digunakan biasanya berskala interval atau rasio. Rumus regresi linier berganda adalah sebagai berikut :

$\mathrm{Y}=\mathrm{a}+\mathrm{b} 1 \mathrm{X}_{1}+\mathrm{b} 2 \mathrm{X}_{2}$

Keterangan

$\mathrm{Y}=$ Variabel dependen (nilai yang diprediksikan)

$\mathrm{X}_{1}, \mathrm{X}_{2}=$ Variabel independen

$\mathrm{a}=$ konstanta (nilai $\mathrm{Y}$ apabila $\mathrm{X}=0$ )

$\mathrm{b}=$ koefisien regresi (nilai peningkatan ataupun penurunan)

Untuk mengetahui signifikan tidaknya pengaruh masing-masing variabel secara individual terhadap variabel terikat, maka dalam penelitian ini peneliti menggunakan analisis uji t. analisis ini digunakan untuk mengetahui apakah terdapat pengaruh yang signifikan dari variabel masing-masing independen yaitu: Motivasi (X1), Kompetensi (X2) terhadap satu variabel dependen, yaitu Kinerja Dosen Tetap (Y). Sedang analisis yang digunakan untuk mengukur besar kecilnya pengaruh atau kontribusi variabel bebas terhadap variabel terikat yang dinyatakan 
dengan persentase dalam rumus yang dikemukakan oleh Sudjana (2000:246) sebagai berikut :

$$
D=R^{2} \times 100 \%
$$

Dimana :

$\mathrm{D}=$ determinasi

$\mathrm{R}^{2}=$ koefisien korelasi berganda

Yang mana nilai D merupakan kuadrat dari $\mathrm{t}$, maka koefisien determinasi tidak pernah negatif dan paling besar sama dengan satu $(0<\mathrm{D}<1)$.

\section{HASIL DAN PEMBAHASAN}

Pembahasan dalam penelitian ini menggunakan analisis regresi linear berganda digunakan untuk mengetahui pengaruh antara satu atau lebih variabel bebas terhadap satu variabel terikat. Hasil analisis regresi linear berganda yang diperoleh dari pengolahan data menggunakan program SPSS yaitu sebagai berikut:

\section{Pengaruh Motivasi Terhadap Kinerja Dosen Tetap Sekolah Tinggi Pariwisata} Bali Internasional

Berdasarkan pengolahan data analisis regresi dengan bantuan program SPSS, diperoleh hasil seperti dimuat pada tabel di bawah ini.

\section{TABEL 1. HASIL ANALISIS MOTIVASI (X) TERHADAP KINERJA DOSEN TETAP (Y)}

\begin{tabular}{|c|c|c|c|c|c|c|}
\hline \multirow{2}{*}{ Model } & \multicolumn{2}{|c|}{$\begin{array}{c}\text { Unstandardized } \\
\text { Coefficients }\end{array}$} & $\begin{array}{c}\text { Standardized } \\
\text { Coefficients }\end{array}$ & \multirow{2}{*}{$\mathrm{t}$} & \multirow{2}{*}{ Sig. } \\
\cline { 3 - 6 } & $\mathrm{B}$ & Std. Error & Beta & & \\
\hline 1 & (Constant) & 4,048 & 1,526 & & 2,652 & 0,010 \\
\hline & Total $\mathrm{X}_{1}$ & 0,204 & 0,097 & 0,295 & 2,096 & 0,040 \\
\hline & Total $\mathrm{X}_{2}$ & 0,238 & 0,086 & 0,388 & 2,756 & 0,008 \\
\hline
\end{tabular}

Berdasarkan Tabel 4.10, diperoleh nilai signifikansi sebesar 0,04 yang berarti lebih kecil dari kriteria signifikan $(0,05)$. Dengan demikian model persamaan regresi berdasarkan data penelitian adalah signifikan.

Adapun persamaan regresi yang dapat ditulis yaitu sebagai berikut:

$\mathrm{Y}=\mathrm{a}+\mathrm{b} 1 \mathrm{X}_{1}+\mathrm{b} 2 \mathrm{X}_{2}$

$\mathrm{Y}=4,048+0,204 \mathrm{X}_{1}+0,238 \mathrm{X}_{2}$

Arti dari persamaan regresi tersebut dapat dijelaskan sebagai berikut:

1. Nilai Konstanta sebesar 4,048 artinya jika variabel motivasi (X1) bernilai nol, maka kinerja dosen tetap (Y) akan memiliki nilai sebesar 4,280.

2. Koefisien regresi X1 sebesar 0,204 artinya jika hubungan motivasi mengalami kenaikan satu satuan maka kinerja dosen akan mengalami peningkatan sebesar 0,204.

Interaksi dari persamaan di atas adalah bahwa Koefisien bernilai positif maka dapat dinyatakan bahwa motivasi (X1) berpengaruh positif terhadap Kinerja Dosen Tetap (Y).

Untuk melakukan uji-t digunakan tabel coefficient, seperti yang telah tercantum pada tabel 4.10 di atas. Uji-t dilakukan untuk mengetahui apakah antara variabel bebas (Motivasi) terhadap variabel terikat (Kinerja Dosen Tetap) mempunyai pengaruh yang nyata atau tidak. Berdasarkan data tabel 4.10 diperoleh $\mathrm{t}_{\text {hitung }}$ sebesar 2,096 pada tingkat sig sebesar 0,04. Hal ini berarti nilai hitung sebesar 
2,096 pada level probabilitas (kepercayaan) 0,05 (95\%) diperoleh tabel sebesar 1,67065. Hasil uji-t tersebut dikaitkan dengan hipotesis pertama yang diajukan dalam penelitian ini yaitu :

Ho : $\beta 1<0$ : menunjukkan tidak terdapat pengaruh antara motivasi terhadap kinerja dosen tetap di Sekolah Tinggi Pariwisata Bali Internasional

$\mathrm{H} 1: \beta 1>0$ : menunjukkan terdapat pengaruh antara motivasi terhadap kinerja Kriteria Pengujian dosen tetap di Sekolah Tinggi Pariwisata Bali Internasional.

a) Jika $t_{\text {hitung }} \leq t_{\text {tabel }}$ maka Ho diterima dan Ha ditolak, signifikansi $>0,05$

b) Jika $t_{\text {hitung }}>t_{\text {tabel }}$ maka Ho ditolak dan Ha diterima, signifikansi $<0,05$ Ttabel $=\mathrm{t}(\mathrm{a} ; \mathrm{n}-\mathrm{k})=\mathrm{t}(0,05,60)=1,67065$

Berdasarkan analisis SPSS diperoleh nilai thitung variabel motivasi sebesar 2.096 dengan signifikansi 0,04. Keputusan uji yaitu Ho ditolak dan H1 diterima, karena $t_{\text {tabel, }}$ yakni 2,096 $>1,67065$ dan nilai signifikansi $<0,05$ yaitu 0,04 .

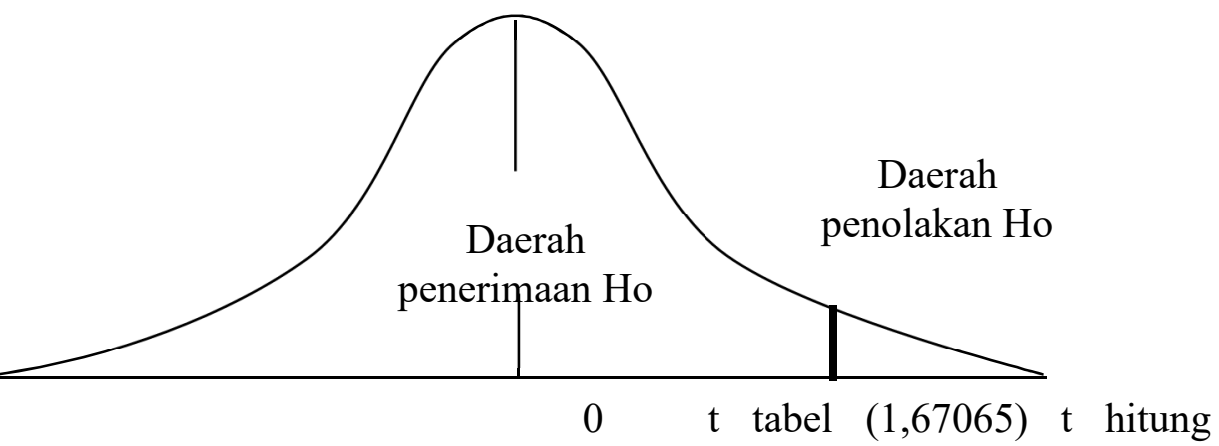

$(2,096)$

\section{GAMBAR 1. KURVA DISTRIBUSI T UJI HIPOTESIS PENGARUH MOTIVASI $\left(\mathrm{X}_{2}\right)$ TERHADAP KINERJA DOSEN (Y)}

Dari analisis regresi linier berganda didapat hasil bahwa Motivasi (X1) berpengaruh positif dan signifikan terhadap Kinerja Dosen Tetap di Sekolah Tinggi Pariwisata Bali Internasional. Dimana persamaan yang didapat adalah $\mathrm{Y}=4,048+$ $0,204 X 1+0,238 X 2$. Nilai koefisien regresi X1 (motivasi kerja) $=0,204$ adalah sangat nyata dengan $t_{\text {hitung }}=2,096$, sig. $=0,04<0,05$ (signifikan). Motivasi yang diberikan Sekolah Tinggi Pariwisata Bali Internasional terhadap dosen tetap yang dapat meningkatkan kinerja dosen dalam bidang pengajaran, penelitian dan pengabdian kepada masyarakat. Hal ini berarti bahwa motivasi berpengaruh secara signifikan terhadap kinerja dosen tetap di Sekolah Tinggi Pariwisata Bali Internasional.

\section{A. Pengaruh Kompetensi Terhadap Kinerja Dosen Tetap Sekolah Tinggi Pariwisata Bali Internasional}

Yang kedua adalah menguji dan menjelaskan pengaruh variabel X2 yaitu kompetensi terhadap kinerja dosen tetap (Y). Hasil pengolahan data dari SPSS dapat terlihat pada tabel di bawah ini. 
TABEL 2. HASIL ANALISIS KOMPETENSI (X $\left.{ }_{2}\right)$ TERHADAP KINERJA DOSEN TETAP (Y)

\begin{tabular}{|c|l|c|c|c|c|c|}
\hline \multirow{2}{*}{ Model } & \multicolumn{2}{|c|}{$\begin{array}{c}\text { Unstandardized } \\
\text { Coefficients }\end{array}$} & $\begin{array}{c}\text { Standardized } \\
\text { Coefficients }\end{array}$ & \multirow{2}{*}{ t } & \multirow{2}{*}{ Sig. } \\
\cline { 3 - 5 } & B & $\begin{array}{c}\text { Std. } \\
\text { Error }\end{array}$ & Beta & & \\
\hline 1 & (Constant) & 4,048 & 1,526 & & 2,652 & 0,010 \\
\hline & Total $\mathrm{X}_{1}$ & 0,204 & 0,097 & 0,295 & 2,096 & 0,040 \\
\hline & Total $\mathrm{X}_{2}$ & 0,238 & 0,086 & 0,388 & 2,756 & 0,008 \\
\hline
\end{tabular}

Dari tabel di atas dapat dilihat bahwa nilai konstanta untuk variabel Kinerja Dosen Tetap adalah 4,048, sedangkan hasil nilai koefisien regresi Kompetensi adalah 0,238. Dengan demikian dapat dibuat persamaan regresi linear dengan mengacu pada rumus sebagai berikut:

$$
\begin{aligned}
& Y=a+b 1 X_{1}+b 2 X_{2} \\
& Y=4,048+0,204 X_{1}+0,238 X_{2}
\end{aligned}
$$

Arti dari persamaan regresi tersebut dapat dijelaskan sebagai berikut:

1. Nilai Konstanta sebesar 4,048 artinya jika variabel Kompetensi (X2) bernilai nol, maka kinerja dosen tetap (Y) akan memiliki nilai sebesar 4,048.

2. Koefisien regresi $\mathrm{X} 2$ sebesar 0,238, artinya jika hubungan kompetensi mengalami kenaikan satu satuan maka kinerja dosen tetap akan mengalami peningkatan sebesar 0,238 .

Interaksi dari persamaan di atas adalah bahwa Koefisien bernilai positif maka dapat dinyatakan bahwa Kompetensi (X2) berpengaruh positif terhadap Kinerja Dosen Tetap (Y).

Untuk melakukan uji-t digunakan tabel coefficient, seperti yang telah tercantum pada tabel 4.11 di atas. Uji-t dilakukan untuk mengetahui apakah antara variabel bebas (Kompetensi) terhadap variabel terikat (Kinerja Dosen Tetap) mempunyai pengaruh yang nyata atau tidak. Berdasarkan data tabel 4.11 diperoleh $t_{\text {hitung }}$ sebesar 2,756 pada tingkat sig sebesar 0,008 . Hal ini berarti nilai $t_{\text {hitung }}$ sebesar 2,756 pada level probabilitas (kepercayaan) 0,05 (95\%) diperoleh $t_{\text {tabel }}$ sebesar 1,67065. Hasil uji-t tersebut dikaitkan dengan hipotesis pertama yang diajukan dalam penelitian ini yaitu :

Ho : $\beta 1,<0$ : menunjukkan tidak terdapat pengaruh antara kompetensi terhadap kinerja dosen tetap di Sekolah Tinggi Pariwisata Bali Internasional

$\mathrm{H} 1: \beta 1>0$ : menunjukkan terdapat pengaruh antara kompetensi terhadap kinerja dosen tetap di Sekolah Tinggi Pariwisata Bali Internasional. Kriteria Pengujian

a) Jika $t_{\text {hitung }} \leq+t_{\text {tabel }}$ maka Ho diterima dan Ha ditolak, signifikansi $>0,05$.

b) Jika $t_{\text {tabel }}$ atau $t_{\text {hitung }}>+t_{\text {tabel }}$ maka Ho ditolak dan Ha diterima, signifikansi $<0,05$.

$\mathrm{T}_{\text {tabel }}=\mathrm{t}(\mathrm{a} ; \mathrm{n}-\mathrm{k})=\mathrm{t}(0,05,60)=1.67065$.

Berdasarkan analisis SPSS diperoleh nilai thitung variabel motivasi sebesar 2,756 dengan signifikansi 0,008. Keputusan uji yaitu Ho ditolak dan H1 diterima, karena $t_{\text {hitung }}>\mathrm{t}_{\text {tabel, }}$ yakni $2,756>1,67065$ dan nilai signifikansi $<0.05$ yaitu 0,008 .

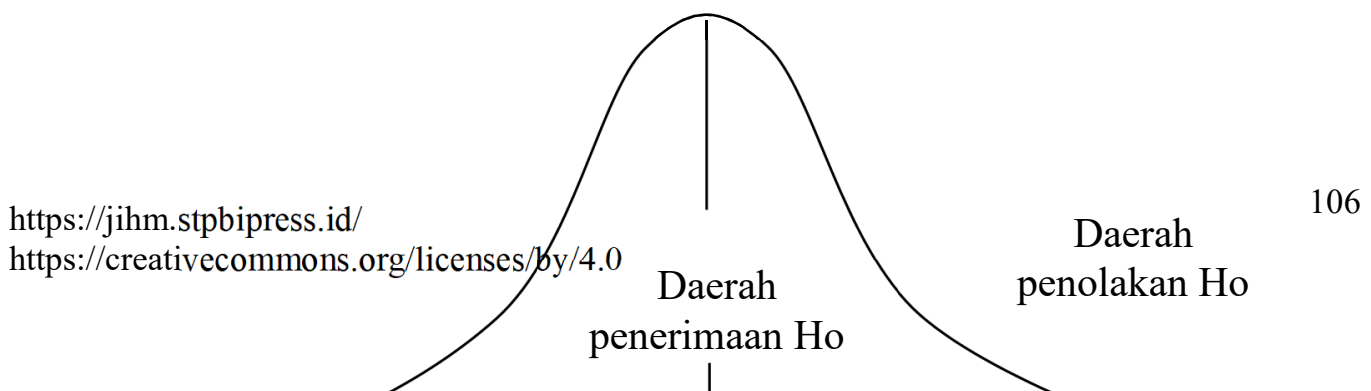




\section{GAMBAR 2. KURVA DISTRIBUSI T UJI HIPOTESIS PENGARUH KOMPETENSI ( $\left.\mathrm{X}_{1}\right)$ TERHADAP KINERJA DOSEN (Y)}

Dari analisis regresi linier berganda didapat hasil bahwa Kompetensi $\left(\mathrm{X}_{2}\right)$ berpengaruh positif dan signifikan terhadap Kinerja Dosen Tetap di Sekolah Tinggi Pariwisata Bali Internasional. Dimana persamaan yang didapat adalah $\mathrm{Y}=4,048+$ $0,204 \mathrm{X} 1+0,238 \mathrm{X} 2$. Nilai koefisien regresi $\mathrm{X}_{2}$ (kompetensi) $=0,365$ adalah sangat nyata dengan $t_{\text {hitung }}=2,756$, sig. $=0,008<0,05$ (signifikan). Kompetensi dosen tetap mampu meningkatkan kinerja dosen tetap di Sekolah Tinggi Pariwisata Bali Internasional. Hal ini berarti bahwa kompetensi berpengaruh secara signifikan terhadap kinerja dosen tetap di Sekolah Tinggi Pariwisata Bali Internasional.

\section{B. Besar Pengaruh Motivasi Dan Kompetensi Terhadap Kinerja Dosen}

\section{Tetap Sekolah Tinggi Pariwisata Bali Internasional}

Untuk melihat pengaruh antara Motivasi dan Kompetensi secara bersamasama terhadap Kinerja Dosen, digunakan analisis regresi berganda dengan bantuan program SPSS, hasil seperti termuat pada tabel di bawah ini:

\section{TABEL 3. HASIL ANALISIS REGRESI LINIER BERGANDA}

\begin{tabular}{|c|l|c|c|l|c|c|}
\hline \multicolumn{2}{|c|}{ Model } & \multicolumn{2}{|c|}{$\begin{array}{c}\text { Unstandardized } \\
\text { Coefficients }\end{array}$} & $\begin{array}{c}\text { Standardized } \\
\text { Coefficients }\end{array}$ & \multirow{2}{*}{$\mathrm{t}$} & \multirow{2}{*}{ Sig. } \\
\cline { 3 - 6 } & B & $\begin{array}{c}\text { Std. } \\
\text { Error }\end{array}$ & Beta & & \\
\hline 1 & (Constant) & 4.048 & 1.526 & & 2.652 & 0.010 \\
\hline & total $\mathrm{X}_{1}$ & 0.204 & 0.097 & 0.295 & 2.096 & 0.040 \\
\hline & Total $\mathrm{X}_{2}$ & 0.238 & 0.086 & 0.388 & 2.756 & 0.008 \\
\hline
\end{tabular}

Dari data yang terlihat pada tabel dapat diketahui bahwa nilai konstanta regresi linear berganda 4.048, dengan nilai koefisien regresi variabel motivasi 0.204 , dan nilai koefisien regresi kompetensi 0.238. Dengan demikian dapat dibuat persamaan regresi linear dengan mengacu pada rumus sebagai berikut :

$$
\begin{aligned}
& \mathrm{Y}=\mathrm{a}+\mathrm{b} 1 \mathrm{X} 1+\mathrm{b} 2 \mathrm{X} 2 \\
& \mathrm{Y}=4.048+0.204 \mathrm{X} 1+0,238 \mathrm{X} 2
\end{aligned}
$$

Arti dari persamaan regresi tersebut dapat dijelaskan sebagai berikut:

1. Konstanta sebesar 4.048 artinya jika variabel motivasi (X1) dan kompetensi (X2) bernilai nol, maka kinerja dosen (Y) akan memiliki nilai sebesar 4.048.

2. Koefisien regresi X1 sebesar 0,204 artinya jika hubungan motivasi mengalami kenaikan satu satuan maka kinerja dosen akan mengalami peningkatan sebesar 0,204 . 
3. Koefisien regresi X2 sebesar 0.238 , artinya jika hubungan kompetensi mengalami kenaikan satu satuan maka kinerja dosen akan mengalami peningkatan sebesar 0,238 .

4. Koefisien regresi X1 sebesar 0,204 dan regresi X2 sebesar 0.238, artinya jika hubungan motivasi dan kompetensi mengalami kenaikan satu satuan maka kinerja dosen akan mengalami peningkatan sebesar 0,204 dan 0,238.

Selanjutnya untuk mengukur tingkat nyata pengaruh variabel Motivasi kerja, Kompetensi secara bersama-sama terhadap kinerja dosen, dilakukan uji F.

TABEL 4. ANOVA

\begin{tabular}{|r|l|r|r|r|r|c|}
\hline \multicolumn{2}{|c|}{ Model } & $\begin{array}{c}\text { Sum of } \\
\text { Squares }\end{array}$ & \multicolumn{1}{c|}{ df } & $\begin{array}{c}\text { Mean } \\
\text { Square }\end{array}$ & F & Sig. \\
\hline 1 & Regression & 44.487 & 2 & 22.244 & 19.937 & 0.000 \\
\hline & Residual & 66.941 & 60 & 1.116 & & \\
\hline & Total & 111.429 & 62 & & & \\
\hline
\end{tabular}

Kreteria pengujian

a) Ho diterima jika Fhitung $<\mathrm{F}(\mathrm{a} ; \mathrm{df1}=\mathrm{k}-1 ; \mathrm{df} 2=\mathrm{n}-\mathrm{k}-1)$ atau signifikansi $>0.05$

b) Ho ditolak jika Fhitung $>\mathrm{F}(\mathrm{a} ; \mathrm{df1}=\mathrm{k}-1$; df2=n-k-1) atau signifikansi $<0.05$

Ftabel $=\mathrm{F}(\mathrm{a} ; \mathrm{df1}=\mathrm{k}-1 ; \mathrm{df} 2=\mathrm{n}-\mathrm{k}-1)=\mathrm{F}(0.05 ; 2 ; 61)=3.148$

Berdasarkan analisis data memakai SPSS diperoleh Fhitung sebesar 19.937 dengan signifikansi sebesar 0.000 . Ho ditolak, karena Fhitung $>$ Ftabel yaitu 19.937 $>3.148$ dan nilai signifikansi $<0.05$ yaitu 0.000 .

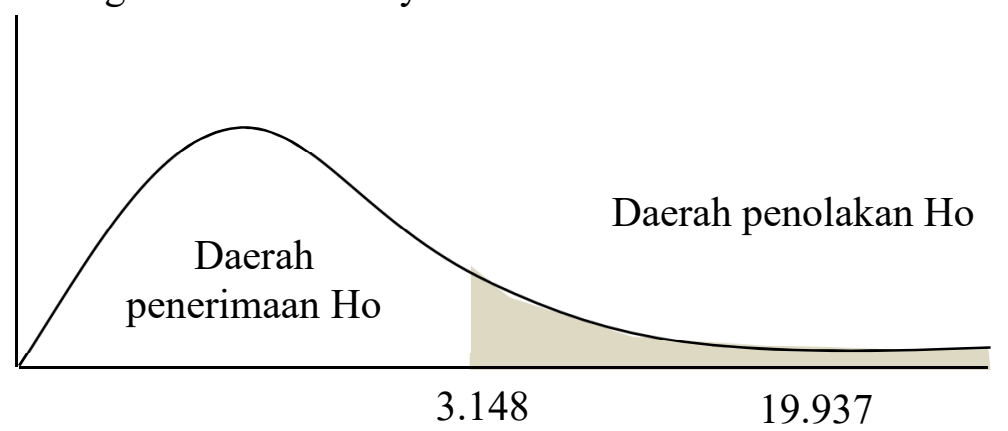

\section{GAMBAR 3. KURVA HIPOTESIS UJI SATU PIHAK}

TABEL 5. MODEL SUMMARY

\begin{tabular}{|c|c|c|c|c|}
\hline Model & $\mathrm{R}$ & $\mathrm{R}$ Square & $\begin{array}{c}\text { Adjusted R } \\
\text { Square }\end{array}$ & $\begin{array}{c}\text { Std. Error of the } \\
\text { Estimate }\end{array}$ \\
\hline 1 & $0,632^{\mathrm{a}}$ & 0,399 & 0,379 & 1,056 \\
\hline
\end{tabular}

Dari tabel model summary di atas dapat diketahui bahwa nilai $\mathrm{R}$ adalah 0,632 , sedangkan nilai $\mathrm{R}^{2}$ sebesar 0,399 . Oleh karena uji koefisien determinasi berganda ini diperoleh dari perhitungan regresi linear berganda, maka koefisien determinasi sebesar 0,399 atau $\mathrm{R}^{2}$ x $100 \%$ sebesar 39,90\%. Kebermaknaan dari nilai tersebut memiliki implikasi bahwa variabel motivasi dan kompetensi berpengaruh positif dan signifikan terhadap kinerja dosen tetap Sekolah Tinggi 
Pariwisata Bali Internasional sebesar 39,90\% dan sisanya 60,10\% dipengaruhi oleh variabel-variabel lain di luar model yang dimasukkan dalam penelitian ini.

\section{SIMPULAN}

Berdasarkan hasil analisis data dan pembahasan pada analisis regresi linier berganda maka dapat disimpulkan bahwa:

1. Pengaruh Motivasi terhadap Kinerja Dosen Tetap di Sekolah Tinggi Pariwisata Bali Internasional adalah berpengaruh positif dan signifikan, yang dibuktikan dari adanya persamaan regresi yaitu: $\mathrm{Y}=4,048+0,204 \mathrm{X} 1+$ $0,238 X 2$. Hal ini menunjukkan bahwa setiap peningkatan motivasi sebesar 1 satuan akan terjadi peningkatan kinerja dosen tetap sebesar 0,204 satuan, yang berarti variabel motivasi berpengaruh positif terhadap kinerja dosen tetap. Selain itu juga dibuktikan dari adanya nilai probabilitasnya lebih kecil dari 0,05 yaitu 0,04 yang mengindikasikan bahwa motivasi berpengaruh signifikan terhadap Kinerja Dosen Tetap di Sekolah Tinggi Pariwisata Bali Internasional.

2. Pengaruh Kompetensi terhadap Kinerja Dosen Tetap di Sekolah Tinggi Pariwisata Bali Internasional adalah berpengaruh positif dan signifikan, yang dibuktikan dari adanya persamaan regresi yaitu: $\mathrm{Y}=4.048+0.204 \mathrm{X} 1+$ $0.238 \mathrm{X} 2$. Hal ini menunjukkan bahwa setiap peningkatan Kompetensi sebesar 1 satuan akan terjadi peningkatan Kinerja Dosen Tetap sebesar 0.238 satuan, yang berarti variabel kompetensi berpengaruh positif terhadap kinerja dosen tetap. Selain itu juga dibuktikan dari adanya nilai probabilitas yang lebih kecil dari 0,05 yaitu 0,008 mengindikasikan bahwa Kompetensi berpengaruh signifikan terhadap Kinerja Dosen Tetap di Sekolah Tinggi Pariwisata Bali Internasional.

Besaran pengaruh motivasi dan kompetensi terhadap kinerja dosen tetap di Sekolah Tinggi Pariwisata Bali Internasional adalah sebesar $39.90 \%$ dan sisanya $60.10 \%$ dipengaruhi oleh variabel-variabel lain di luar model yang dimasukan dalam penelitian ini.

\section{DAFTAR PUSTAKA}

Arikunto,S.,2010. Prosedur Penelitian : Suatu Pendekatan Praktik. Rineka Cipta.Jakarta

Algifari. 2000. Analisis Teori Regresi: Teori Kasus dan Solusi. BPFE: Yogyakarta. Agustina, 2012. Pengaruh Persepsi Dukungan Organisasi (Perceived Organizational Support) Terhadap Kinerja Dosen Melalui Motivasi Kerja (Studi Pada Sekolah Tinggi Ilmu Ekonomi STIE Palangka Raya),Jurnal Sains Manajemen

Depdiknas. 2003. Data Kelayakan Mengajar Guru. Jakarta: Depdiknas.

Fu'ad, E. N., 2015. Pengaruh Iklim Organisasi dan Motivasi Terhadap Kinerja Dosen di Sekolah Tinggi Ilmu Ekonomi Nahdlatul Ulama (STIENU) Jepara. Jurnal Sains Manajemen, 1(1), pp. 49-71.

Fahmi, (2014). Perilaku Organisasi: Teori, Aplikasi, dan Kasus. Penerbit Alfabeta, Bandung. 
Hakim, L., 2011. Pengaruh Motivasi Kerja Terhadap Kinerja Dosen STIE Totalwin Semarang. Jurnal Ilmu Manajemen dan Akuntansi Terapan, 2(2), pp. 2737.

I'tidal, M. \& Jam'al, A., 2016. Pengaruh Antara Kompetensi, Kompensasi, Motivasi Kerja dan Pendidikan Terhadap Terhadap Kinerja Dosen di STIMIK AKBA Makasar. Jurnal Competitiveness, 10(2), pp. 16-30.

Kholik, A., 2016. Pengaruh Kompetensi Dosen dan Kepuasan Kerja Dosen Terhadap Kinerja Dosen di Universitas Djuanda Bogor, Surakarta: Pascasarjana Program Studi Manajemen Pendidikan Islam Institut Agama Islam Negeri Surakarta.

Kusumawijaya, I. K., 2014. Upaya Meningkatkan Produktivitas Kerja dengan Pelatihan dan Motivasi Kerja pada Kelompok Tani Tanaman Hias Gunasari Desa Petiga, Tabanan. Jurnal Manajemen dan Akuntansi STIE Triatma Mulya , 20(2), pp. 195-208.

Manik, S. \& Nova, S., 2018. Pengaruh Kompetensi Terhadap Kinerja Dosen Sekolah Tinggi Ilmu Ekonomi Riau. Jurnal Ilmiah Ekonomi dan Bisnis , 15(1), pp. 1-11.

Martinis, (2006). Profesionalisasi Guru dan Implementasi Kurikulum Berbasis Kompetensi. Jakarta: Gaung Persada Press

Mulyasa, (2012) "Kurikulum Yang Disempurnakan Pengembangan Standar Kompetensi dan Kompetensi Dasar",

Nur'aeni, 2011. Pengaruh Motivasi, Kompetensi dan Komitmen Terhadap Kinerja Dosen Perguruan Tinggi Swasta di Kopertis Wilayah II Palembang. Jurnal Manajemen dan Bisnis, 1(2), pp. 101-129.

Pramudyo, A., 2010. Analisis Faktor-Faktor yang Mempengaruhi Kinerja Dosen Negeri Dipekerjakan pada Kopertis Wilayah V Yogyakarta. JBTI, 1(1), pp. $1-11$.

Presiden Republik Indonesia , 2012. Undang Undang Republik Indonesia Nomor 12 Tahun 2012 Tentang Pendidikan Tinggi, Jakarta: Menteri Hukum dan Hak Asasi Manusia.

Prawirosentono, (2011). Kinerja. Bandung: Alfabeta.

Rahayu, Y., 2013. Pengaruh Motivasi dan Kompetensi terhadap Kinerja Dosen Tidak Tetap/Luar Biasa di Perguruan Tinggi Swasta Kota Sukabumi. Sukabumi, kampus BSI Kalimalang, pp. 65-76.

Rina, 2017., Pengaruh Kompetensi, Budaya Organisasi dan Motivasi Terhadap Kinerja Dosen Perguruan Tinggi Swasta di Kota Makasar. Jurnal Riset Edisi XIX, 3(008), pp. 88-100.

Rivai, 2010., Manajemen Sumber Daya Manusia untuk Perusahaan dari Teori ke Praktik.Jakarta : PT. Raja Grafindo.

Sudjana, N., 2002. Dasar-dasar Proses Belajar Mengajar. 1st ed. Bandung: Sinar Baru Algensindo.

Sufianti, \& Permana., 2015. Pengaruh Motivasi Kerja dan Kompetensi Profesional Terhadap Kinerja Dosen di Sekolah Tinggi Pariwisata Bandung. Jurnal Administrasi Pendidikan, 22(1), pp. 14-25.

Sugiyono,2017, Metode Penelitian Kuantitatif, Kualitatif dan R\&D.Edisi ke 26.Alfabeta.Bandung 
Sutrisno, (2015). Manajemen Sumber Daya Manusia. Kencana Prenada Media Group, Jakarta.

Suparlan. (2006). Guru Sebagai Profesi. Yogyakarta: Hikayat Publishing

Taruno, F. S. C. d., 2012. Pengaruh Gaya Kepemimpinan Terhadap Kinerja Dosen Dengan Kepuasan Kerja Dan Motivasi Kerja Sebagai Mediator (Studi Pada Perguruan Tinggi Swasta Di Jayapura. Jurnal Aplikasi Manajemen, 10(3), pp. 1693-5241.Use the "Insert Citation" button to add citations to this document.

Undang-Undang Republik Indonesia No.12 Tahun 2012 tentang Pendidikan Tinggi, Tri Dharma Perguruan Tinggi 